\title{
ANALISIS HIDROLIKA PENAMPANG ALAMI DI SUNGAI UNDA HILIR
}

\author{
Putu Gita Widiarsini $^{1}$, I P. Gustave Suryantara Pariartha ${ }^{2}$ dan Mawiti Infantri Yekti ${ }^{3}$ \\ ${ }^{1,2,3}$ Program Studi Magister Teknik Sipil Universitas Udayana Denpasar Bali \\ Email: widiarsinigita@gmail.com \\ doi: https://doi.org/10.24843/SPEKTRAN.2021.v09.i01.p10
}

\begin{abstract}
ABSTRAK
Aliran Sungai Unda mengalir dalam Daerah Aliran Sungai (DAS) Unda dan melalui Kabupaten Klungkung dengan panjang sungai 22,6 km dan luas 230,9 km2 dengan tipe sungai adalah perennial. Pada saat terjadi banjir lahar dingin akibat erupsi Gunung Agung, sempadan sungai dengan tanggul alami di Sungai Unda hilir mengalami kerusakan akibat derasnya arus sungai yang mengalir dari hulu menuju hilir. Selain itu di hilir Sungai Unda ada bekas galian C dari letusan Gunung Agung sebelumnya. Akibat letusan Gunung Agung 2017 menyebabkan perubahan geometri hidrolis penampang sungai, termasuk tanggul alami dan lokasi galian $\mathrm{C}$ tersebut. Berdasarkan kondisi ini perlu dilakukan analisis penampang geometri Sunga Unda hilir menggunakan software HEC-HMS dan HEC-RAS.

Hasil running awal berdasarkan debit banjir kala ulang 50 tahun sebesar $350,3 \mathrm{~m}^{3} /$ detik menyebabkan luapan air pada penampang alami di hilir sungai yaitu antara UD 3 sampai dengan UD 11 setinggi 1,5 meter sampai dengan 3,0 meter sepanjang 1052,34 meter ke arah hilir. Posisi ini berada di hilir jembatan By Pass Ida Bagus Mantra. Running HEC-RAS dilanjutkan dengan merencanakan tinggi tanggul antara 2,0 meter sampai dengan 2,5 meter pada posisi UD 3 sampai dengan UD 11. Hasil running menyatakan sudah tidak terjadi luapan pada desain tanggul antara 2,0 meter sampai dengan 2,5 meter.
\end{abstract}

Kata kunci: penampang alami hilir sungai, analisis hidrologi, analisis hidrolika, tanggul sungai

\section{NATURAL CROSS-SECTIONAL HYDRAULIC ANALYSIS IN LOWER UNDA RIVER ABSTRACT}

Unda River flows in the Unda watershed and through Klungkung Regency with a river length of 22.6 $\mathrm{km}$ and a river area of $230.9 \mathrm{~km} 2$ with the type of river is perennial. During the cold lava flood caused by the eruption of Mount Agung, the border of the river with a natural embankment in the lower Unda River was damaged by the rapid flow of the river flowing from upstream to downstream. In addition, downstream of the Unda River there are traces of excavation C from the previous eruption of Mount Agung. The result of the eruption of Mount Agung 2017 caused changes in the geometry of the river cross-sectional hydrolysis, including natural embankments and the location of the $\mathrm{C}$ excavation. Based on these conditions, it is necessary to do cross-sectional analysis of Sunga Unda downstream geometry using HEC-HMS and HEC-RAS software.

The initial running result based on flood discharge during the 50-year anniversary of $350.3 \mathrm{~m} 3 / \mathrm{s}$ caused water overflow in the natural cross-section downstream of the river between UD 3 to UD 11 as high as 1.5 meters to 3.0 meters along 1052.34 meters downstream. This position is downstream of the By Pass Ida Bagus Mantra bridge. Running HEC-RAS continued by planning the height of the embankment between 2.0 meters to 2.5 meters at the position of UD 3 to UD 11. The running results stated that there was no overflow on the embankment design between 2.0 meters to 2.5 meters.

Keywords: natural cross-section of downstream rivers, hydrological analysis, hydraulic analysis, river embankments 


\section{PENDAHULUAN}

DAS Unda merupakan DAS lintas kabupaten yang memilki total luas 223,07 km² dengan luas untuk Kabupaten Karangasem 200,46 km², Kabupaten Klungkung 11,43 km², Kabupaten Bangli 11,18 km² (Balai Wilayah Sungai Bali-Penida, 2017). Sungai Unda terdiri dari 7 Subbasin diantaranya: Subbasin-Barak, Subbasin-Bejing, Subbasin-Krekuk, Subbasin-Masin, Subbasin-Mangening, Subbasin-Sah, Dan SubbasinTelagawaja. Batas Hulu Sungai Unda berlokasi di Desa Selat Kabupaten Klungkung dan batas hilir Sungai Unda berlokasi di Banjar Karangdadi dan Banjar Pasurungan, Desa Kusamba, Kecamatan Dawan, yang bermuara ke Selat Badung (Pidada et al., 2018). Pada bulan November tahun 2017 terjadi letusan Gunung Agung yang menyebabkan banjir lahar dingin di sebagian sungai di Bali, salah satunya Sungai Unda yang terkena dampak akibat letusan tersebut. Warga yang bermukim di sepanjang bantaran sungai tidak bisa melakukan kegiatan sehari-hari akibat kondisi aliran air yang berlumpur dan bau menyengat (Mustofa, 2017).

Berdasarkan hasil survei yang dilakukan di Sungai Unda hulu yaitu desa Selat tahun 2020, didapatkan kondisi penampang alami sungai menyempit akibat ditumbuhi rumput dan endapan material vulkanik akibat banjir lahar dingin. Pada saat terjadi banjir lahar dingin akibat erupsi Gunung Agung, sempadan sungai dengan tanggul alami di Sungai Unda hilir mengalami kerusakan akibat derasnya arus sungai yang mengalir dari hulu menuju hilir. Selain itu di hilir Sungai Unda ada bekas galian C dari letusan Gunung Agung sebelumnya. Akibat letusan Gunung Agung 2017 menyebabkan perubahan geometri hidrolis penampang sungai, termasuk tanggul alami dan lokasi galian $\mathrm{C}$ tersebut. Berdasarkan kondisi tersebut menurut buku Pola PSDA 2017 BWS-Bali Penida, perlu dilakukan rencana penataan kawasan dengan diawali analisis hidrologi dan hidrolika pada penampang alami Sungai Unda dengan tujuan mengembalikan fungsi utama dari sungai tersebut dalam mengalirkan air menuju muara.

\section{JUDUL TEORI PENDUKUNG}

\section{$2.1 \quad$ ANALISIS HIDROLOGI}

Analisis hidrologi bertujuan mendapatkan debit banjir rencana dengan kala ulang yang ditentukan. Tahap-tahap dari analisis hidrologi dapat dilihat pada penjabaran sebagai berikut. Adapun parameterparameter yang digunakan dalam analisis hidrologi yaitu mencari nilai rata-rata hitung, melakukan analisis simpangan baku (standar deviasi), selanjutnya mencari nilai koefisien variasi, nilai kemencengan (koefisien skewness) dan koefisien kurtosis (Marthina et al., 2014). Tahapan-tahapan dari analisis hidrologi dapat dilihat pada penjabaran sebagai berikut.

\subsubsection{Uji Konsistensi Data Metode RAPS}

Metode RAPS (Rescaled Adjusted Partial Sum) memiliki fungsi yang sama dengan metode (Double Mass Analysis) yaitu untuk menentukan ketidakonsistenan data curah hujan yang digunakan. Data dinyatakan panggah apabila nilai $\mathrm{Q} / \sqrt{ }$ n lebih kecil dari nilai kritik untuk tahun dan confidence level yang sesuai, data dinyatakan panggah (Lashari et al., 2017). Pengujian ini dilakukan dengan kumulatif penyimpangan kuadrat terhadap nilai reratanya (Fadlillah et al., 2018).

\subsubsection{Uji Kesesuaian Distribusi}

Dalan mengestimasi banjir rencana atau debit diperlukan perhitungan analisis frekuensi. Analisis frekuensi yang digunanakan belum tentu sesuai dengan distribusi yang dipilih, sehingga diperlukan uji kesesuaian distribusi. Uji kesesuaian distribusi dilakukan untuk menjamin pendekatan empiris (berupa pengeplotan data) yang diwakilkan oleh kurva teoritis. Metode uji chi-square dan uji smirnov kolmogorof merupakan 2 metode yang bisa digunakan untuk analisis uji kesesuaian distribusi (Montarcih, 2009). Penyimpangan yang terjadi biasanya dikarenakan kesalahan-kesalahan yang kebetulan (Sarminingsih, 2018). Adapun tahap-tahap analisis hidrologi dapat dilihat pada penjabaran sebagai berikut.

\subsubsection{Intensitas-Durasi-Frekuensi (IDF)}

Bentuk kurva yang menjelaskan hubungan antara intensitas hujan dalam bentuk ordinat, kemudian durasi hujan sebagai absis serta beberapa grafik yang menunjukan frekuensi atau periode ulang disebut dengan Intensitas-Durasi-frekuensi (IDF) dengan tujuan memperkirakan debit puncak di daerah tangkapan kecil, seperti gorong-gorong, jembatan, dan system drainase kota (Triatmodjo, 2008).

$$
I_{t}=\frac{R_{24}}{24}\left(\frac{24}{t}\right)^{\frac{2}{3}}
$$

dengan:

$\mathrm{I}_{\mathrm{t}} \quad$ : intensitas curah hujan untuk lama hujan $t(\mathrm{~mm} / \mathrm{jam})$. 
t : lamanya curah hujan (jam).

$\mathrm{R}_{24}$ : curah hujan maksimum selama 24 jam (mm).

\subsubsection{Hidrograf Satuan Sintetis Nakayasu}

Beberapa sungai di Jepang menggunakan HSS Nakayasu (Triatmodjo, 2008). Dalam analisis Hidrograf Satuan Sintetik Nakayasu ada beberapa parameter yang digunakan diantaranya (Kawet and Halim, 2013).

1. Tenggang waktu dari permulaan hujan sampai puncak hidrograf (Time to Peak Magitude)

2. Tenggang waktu dari titik berat hujan sampai titik berat hidrograf (Time Lag)

3. Tenggang waktu hidrograf (Time Base of Hydrograph)

4. Luas daerah pengaliran (Catchment Area)

5. Panjang alur sungai utama terpanjang ((Length of The Longest Channel)

6. Koefisien pengaliran (Run off Coefficient)

$Q_{p}=\frac{1}{3,6}\left(\frac{A \cdot R_{0}}{0,3 T_{P+T_{0,3}}}\right)$

dengan:

Qp = Debit puncak banjir

$\mathrm{C} \quad=$ Koefisien aliran

A $\quad=$ Luas das sampe ke outlet $\left(\mathrm{km}^{2}\right)$

Ro = Hujan satuan $(\mathrm{mm})$

$\mathrm{Tp} \quad$ = Waktu yang diperlukan dari permulaan hujan sampai puncak banjir (jam)

$\mathrm{T}_{0,3} \quad=$ Waktu yang diperlukan oleh penurunan debit, dari debit puncak sampai menjadi $30 \%$ dari debit puncak (jam).

\subsubsection{Debit banjir rencana dengan pemodelan (HEC-HMS)}

Data hidrograf banjir terukur dan hidrograf banjir model merupakan dua jenis data yang digunakan dalam pemodelan hydrologic engineering center-the hydrologic modeling system (HEC-HMS). Data Hidrograf banjir terukur diperoleh dari data hujan-aliran, sedangkan data debit aliran ditentukan dari pencatatan tinggi muka air dengan persamaan lengkung aliran (rating curve). Analisis hidrograf banjir model HEC-HMS memiliki parameter, diantaranya: (Suprayogi, 2012).

1. Basin model yang terdiri dari elemen-elemen sungai yang terhubung dengan parameter sungai.

2. Meteorologic model terdiri dari data hujan dan penguapan.

3. Control Specifications berisikan waktu mulai hingga akhir perhitugan.

Terdapat beberapa komponen lainnya selain tiga komponen di atas yaitu:

1. Time series data yang berhubungan dengan data hujan, data debit

2. Paired data terdapat data hidrograf satuan.

Validasi sungai model merupakan proses untuk mendapatkan sebuah gambaran tingkat ketidakpastian dalam memprediksi siklus hidrologi. Secara visual koheresi/ kemiripan dapat di lihat dari output terukur yang mewakili alam serta output hitung yang mewakili simulasi sebuah model. (Suprayogi, 2012).

Tabel 2.1 Rentang Nilai Parameter Model

\begin{tabular}{lll}
\hline \multicolumn{1}{c}{ Model } & \multicolumn{1}{c}{ Parameter } & \multicolumn{1}{c}{ Range Nilai } \\
\hline Initial and constantrate & Initial loss & $0-500 \mathrm{~mm}$ \\
Loss & Constant loss rate & $0-300 \mathrm{~mm} / \mathrm{jam}$ \\
SCS loss & Initial abstraction & $0-500 \mathrm{~mm}$ \\
& Curve Number & $1-100$ \\
Snyder's $U H$ & Lag & $0.1-500 \mathrm{jam}$ \\
& Cp & $0.1-1$ \\
Baseflow & Initial basflow & $0-100000 \mathrm{~m} 3 / \mathrm{dt}$ \\
& Recession factor & 0,000011 \\
& Flow to peak ratio & $0-1$
\end{tabular}




\begin{tabular}{lll} 
Muskingum routing & $K$ & $0,1-150$ jam \\
& $X$ & $0-0,5$ \\
& Number of steps & $1-100$ \\
\hline
\end{tabular}

Sumber: HEC-HMS,2000

\subsubsection{SCS Curve Number}

Metode CN merupakan pendekatan empirik yang menghubungkan antara hujan, tutupan lahan, dan kelompok hidrologis tanah. Satuan pemetaan ini berdasarkan analisis data penginderaan jauh. Antecedent Moisture Conditions (AMC) atau biasa disebut kelembaban tanah sebelumnya perlu diketahui lebih dahulu untuk menentukan nilai CN. Tanah yang mampu menghasilkan air permukaan besar adalah kondisi jenuh air, apabila menghasilkan sedikit aliran permukaan dikategorikan tanah kondisi kering (Tikno et al., 2016). Nilai dari CN (Curve Number) bervariasi dari 100 (untuk perumukaan yang digenangi air), sekitar 30 (untuk permukaan tak kedap air dengan nilai infiltrasi tinggi) (Affandy and Anwar, 2011). Dalam mencari CN yang dijelaskan dalam rumusan NEH - 4 (SCS 1986) sebagai berikut:

$$
\mathrm{Q}=\frac{\left(P-I_{a}\right)^{2}}{P-I_{a}+S}
$$

dengan:

$\mathrm{Q}=\quad=$ Tebal aliran permukaan / runoff $(\mathrm{mm})$

$\mathrm{P} \quad=$ Curah hujan $(\mathrm{mm})$

$\mathrm{S} \quad=$ retensi air potensial maksimum atau kapasitas penyimpanan maksimum setelah run-off terjadi atau air yang terinfiltrasi ke dalam tanah $(\mathrm{mm})$

dengan:

$\mathrm{S}=\frac{25400}{C N}-254$

\subsubsection{Menentukan nilai Impervious Area}

Daerah permukiman kerapatan vegetasi 35\% (65\% daerah kedap air) terdapat daerah pertokoan atau pusat perekonomian (85\% daerah kedap air) dan daerah industry diidentifikasikan sebagai area kedap air. $100 \%$ hujan yang jatuh di permukaan tanah menjadi aliran permukaan diasumsikan sebagai area kedap air (Suprayogi, 2012).

\subsection{ANALISIS HIDROLIKA}

2.2.1 Software HEC-RAS (Hydrologic Engineering Center-River Analysis System)

Software HEC-RAS digunakan dalam pemodelan aliran di sungai. US Army Corps of Engineers (USACE) menaungi Hydrologic Engineering Center (HEC) yang merupakan satu divisi di dalam Institute for Water Resources (IWR) dalam pembuatan River Analysis System (RAS). HEC-RAS merupakan model satu dimensi aliran permanen maupun tak permanen (steady and unsteady one-dimensional flow model). 1) hitungan profil muka air aliran permanen, 2) simulasi aliran tak permanen, 3) hitungan transpor sedimen dan 4) hitungan kualitas air merupakan empat model satu dimensi yang terdapat dalam HEC-RAS. HEC-RAS merupakan program aplikasi yang mengintegrasikan fitur graphical user interface, analisis hidraulik, manajemen dan penyimpanan data, grafik, serta pelaporan (Wigati and Soedarsono, 2016). Tujuan analisis HEC-RAS untuk memberikan infomasi terkait profil aliran geometri di sungai.

Data-data yang diperlukan dalam menganalisis penampang sungai dengan menggunakan software HECRAS adalah:

1. Penampang memanjang Sungai Unda.

2. Penampang melintang Sungai Unda.

3. Data debit yang melalui Sungai Unda.

4. Angka koefisien kekasaran manning.

5.Geometri aliran Sungai Unda. 


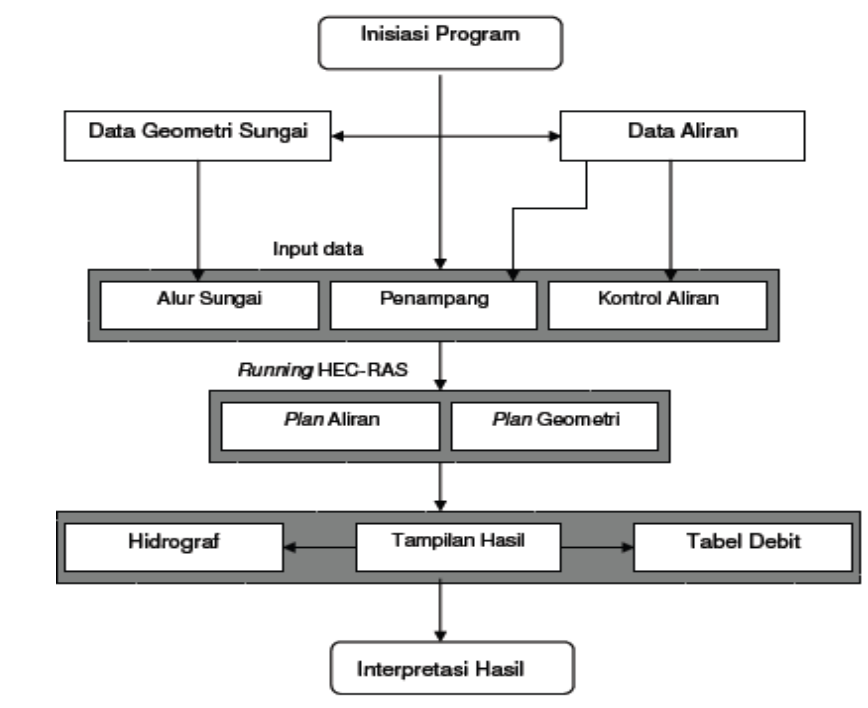

Gambar 2.1 Diagram Alur Pemodelan Hidrolika dengan HEC-RAS

(Sumber:Istiarto, 2014)

\section{3}

\section{METODE}

Pada penelitian ini terdapat permasalahan yang dibahas yaitu upaya untuk mendukung konservasi sumber daya air, yaitu mengembalikan fungsi utama dari sungai tersebut dalam mengalirkan air menuju muara dengan melakukan analisis hidrologi dan hidrolika penampang alami Sungai Unda hilir sesuai dengan buku PSDA 2017 BWS-Bali Penida. Lokasi penelitian ini dilakukan di Sungai Unda hilir yang masuk pada wilayah Kabupaten Klungkung.

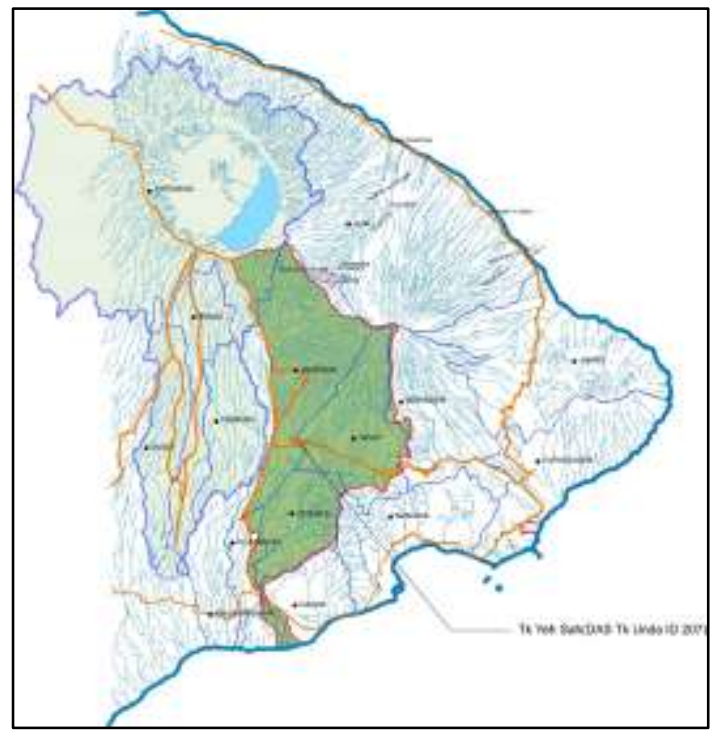

Gambar 3.1 Lokasi Sungai Unda

(Sumber: Konsultan Cv. Prema Wangun Jaya 2017)

Data sekunder yang dibutuhkan untuk analisisis hidrologi di dapatkan dari Balai Besar Wilayah Sungai BaliPenida berupa data curah hujan. Adapun data crosssection sungai, geometri hidrolis penampang sungai didapatkan dari konsultan CV. Prema Wangun Jaya, 2017 yang digunakan dalam analisis hidrolika sungai.

Analisis pertama yang dilakukan adalah analisis hidrologi untuk hujan kawasan, analisis frekuensi, dan intensitas curah hujan jam-jaman pada wilayah studi berdasarkan data curah hujan harian maksimum. Untuk mendapatkan Q banjir rencana dengan kala ulang 50 tahun dilakukan pemodelan software HEC-HMS. Kemudian 
dillanjutkan analisis hidrolika menggunakan software HEC-RAS untuk mencari profil aliran geometri di Sungai Unda hilir.

\section{PEMBAHASAN}

\subsection{ANALISIS HEC-HMS}

Analisis hidrologi menggunakan pemodelan HEC-HMS. Adapun Langkah-langkah awal yaitu dengan membuat pemodelan basin dengan memasukkan gambar Sub-DAS Unda yaitu Subbasin- Pule Subbasin- Telaga Waja, dan Subbasin-Panti terlihat pada Gambar 4.1.

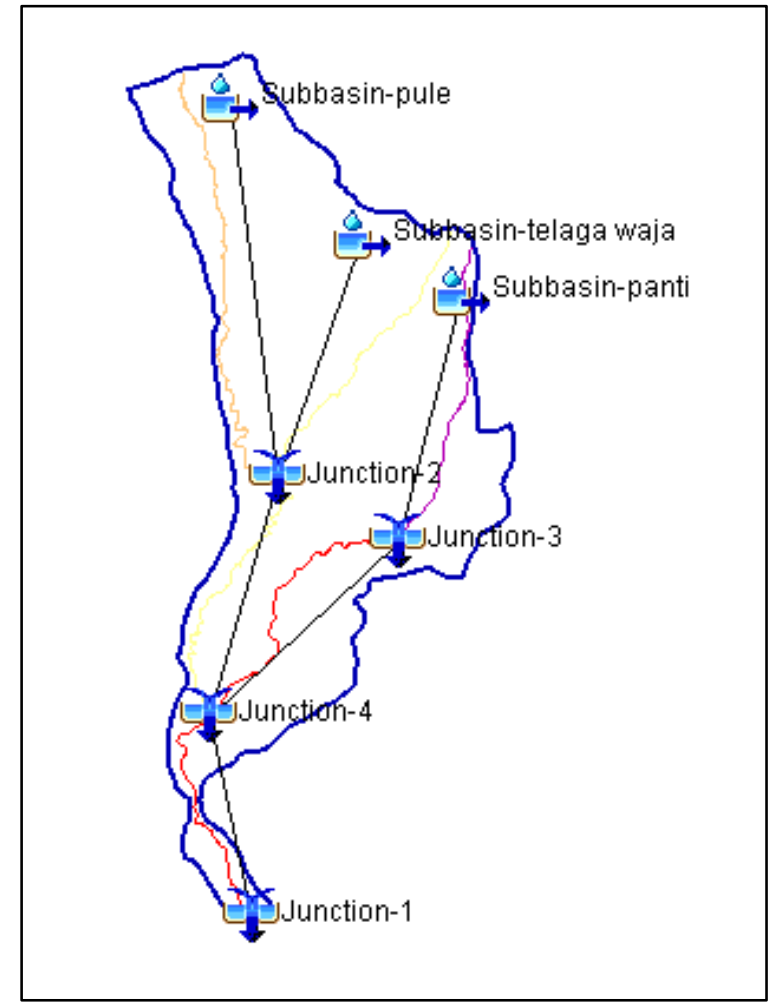

Gambar 4.1 Model basin pada wilayah studi

Setelah parameter diimput ke dalam pemodelan HEC-HMS selanjutnya dilakukan simulasi dengan hasil pada Gambar 4.2

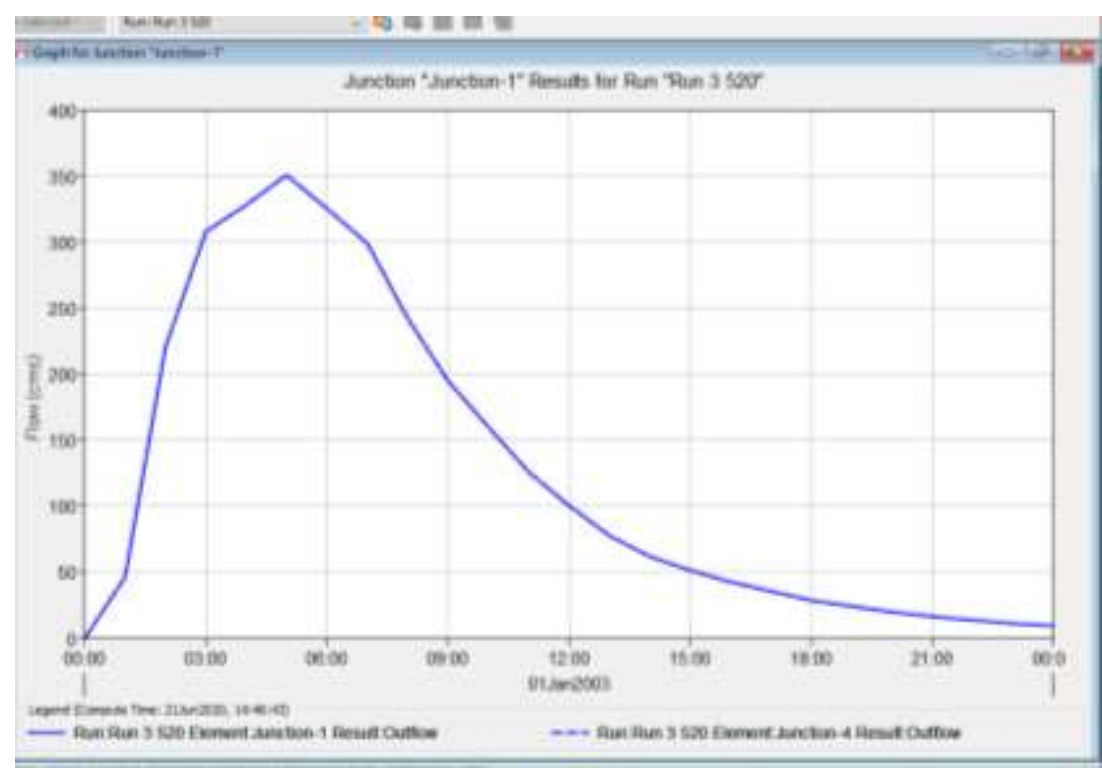

Gambar 4.2 Grafik Hidrograf Banjir Kala Ulang 50 tahun dengan Pemodelan HEC-HMS 
Tabel 4.1 Hasil Summary dengan Pemodelan HEC-HMS

\begin{tabular}{ccccc}
\hline Hydrologic Element & Luas Genangan & Debit Limpasan & Waktu Limpasan & Volume \\
\hline Junction-2 & $\mathrm{Km}^{2}$ & $\mathrm{~m}^{3} / \mathrm{s}$ & & $(\mathrm{mm})$ \\
Junction-3 & 107,85 & 243,20 & $05: 00$ & 71,26 \\
Subbasin-telaga waja & 42,86 & 135,80 & $03: 00$ & 79,75 \\
Subbasin-panti & 41,62 & 90,00 & $05: 00$ & 63,95 \\
Subbasin-pule & 42,86 & 135,80 & $03: 00$ & 79,75 \\
Junction-4 & 66,23 & 153,20 & $05: 00$ & 75,85 \\
Junction-1 & 150,71 & 350,30 & $05: 00$ & 73,67 \\
\hline
\end{tabular}

Pada Tabel 4.1 diketahui puncak banjir terjadi pada jam ke-5 sebesar $350.3 \mathrm{~m}^{3} /$ detik. Wilayah pembagian Sub-DAS yang memiliki debit limpasan tinggi terdapat di Subbasin-pule Pule sebesar $153,2 \mathrm{~m}^{3} /$ detik. Sedangkan untuk daerah dengan debit puncak terkecil terdapat pada Subbasin-telaga waja Telaga Waja sebesar $90 \mathrm{~m}^{3} / \mathrm{detik}$.

\subsection{ANALISIS HEC-RAS}

Pada perhitungan hidrolika parameter yang di imput diantaranya Peta pengukuran wilayah studi, cross section, kemiringan sungai, serta debit hasil analisis HEC-HMS. Pada pemodelan HEC-RAS yang ditinjau hanyalah sungai utamanya yaitu Sungai Unda bagian hilir. Berikut peta pengukuran Sungai Unda seperti Gambar 4.4 dan hasil simulasi HEC-RAS seperti Tabel 4.2 di bawah ini.

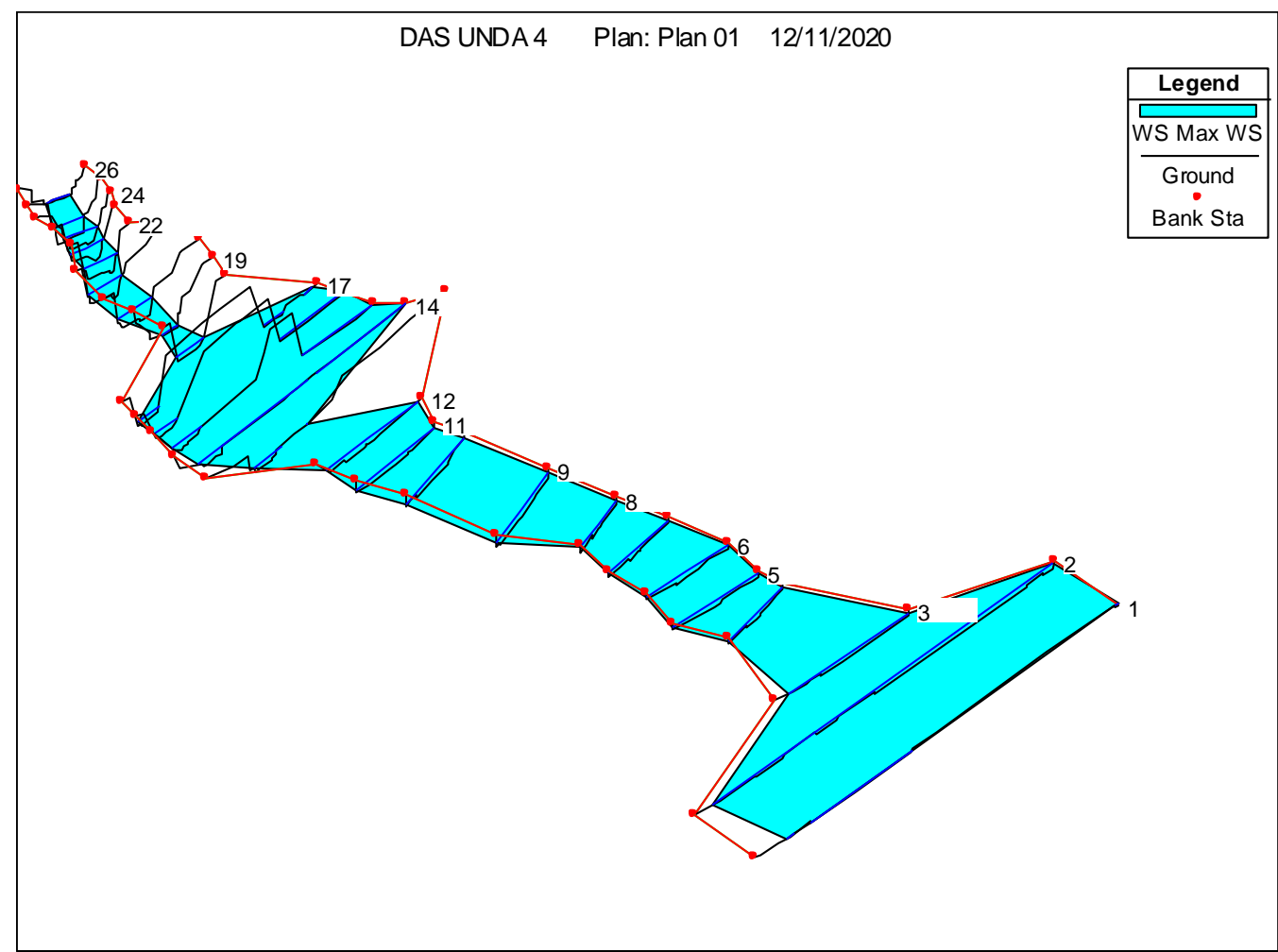

Gambar 4.3 Perspektif 2D Aliran Sungai Unda 


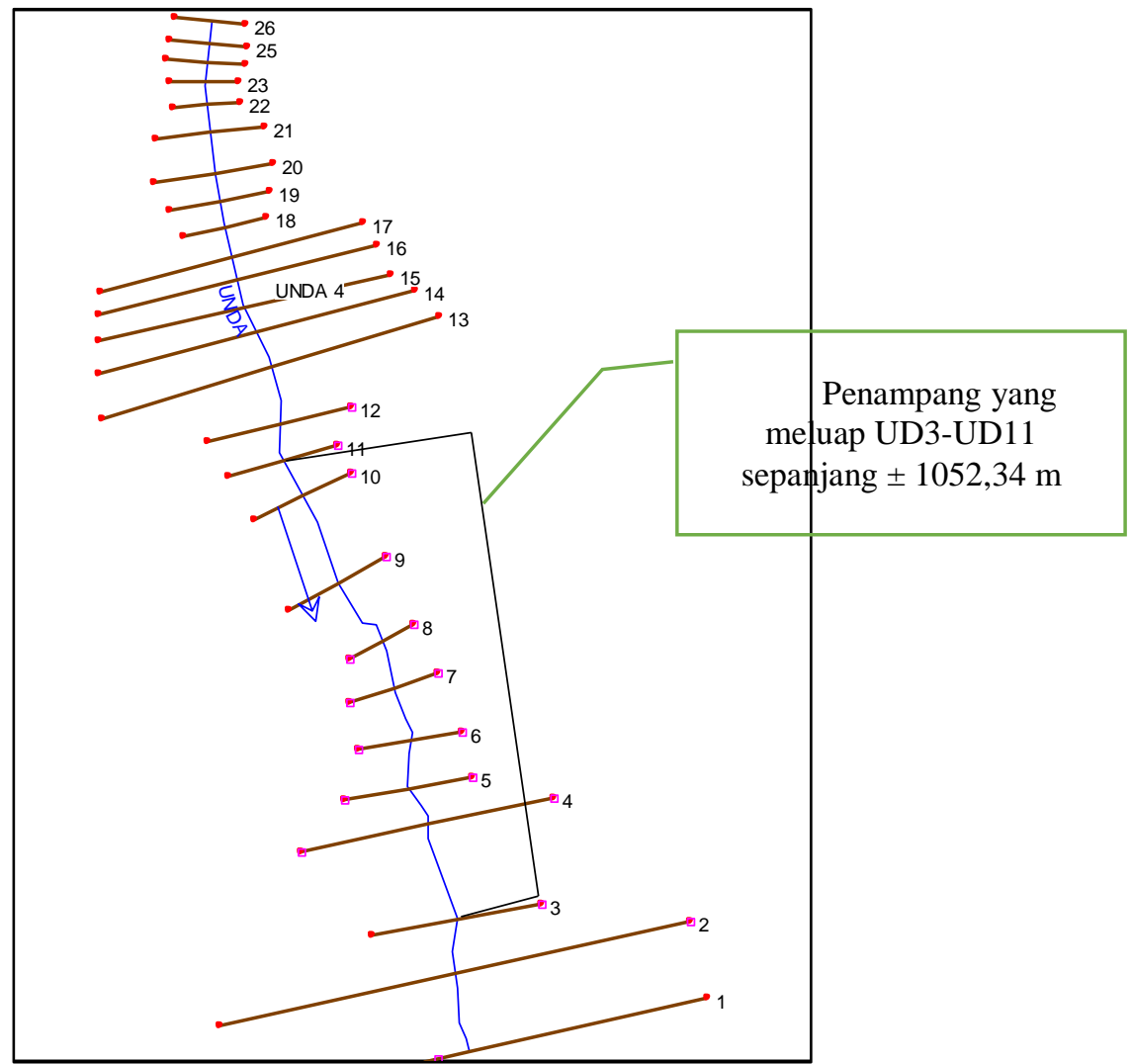

Gambar 4.4 Pemodelan Geometri Sungai Unda Pada HEC-RAS

Penampang alami yang mengalami luapan air seperti Gambar 4.4 diatas akan di running dengan kala ulang 50 tahun menggunakan software HEC-RAS guna mendapatkan tinggi muka air banjir setelah dilakukan perencanaan tinggi tanggul di penampang yang mengalami luapan seperti Tabel 4.2 di bawah ini.

Tabel 4.2 Hasil Simulasi Peninggian Tanggul pada Penampang yang Meluap

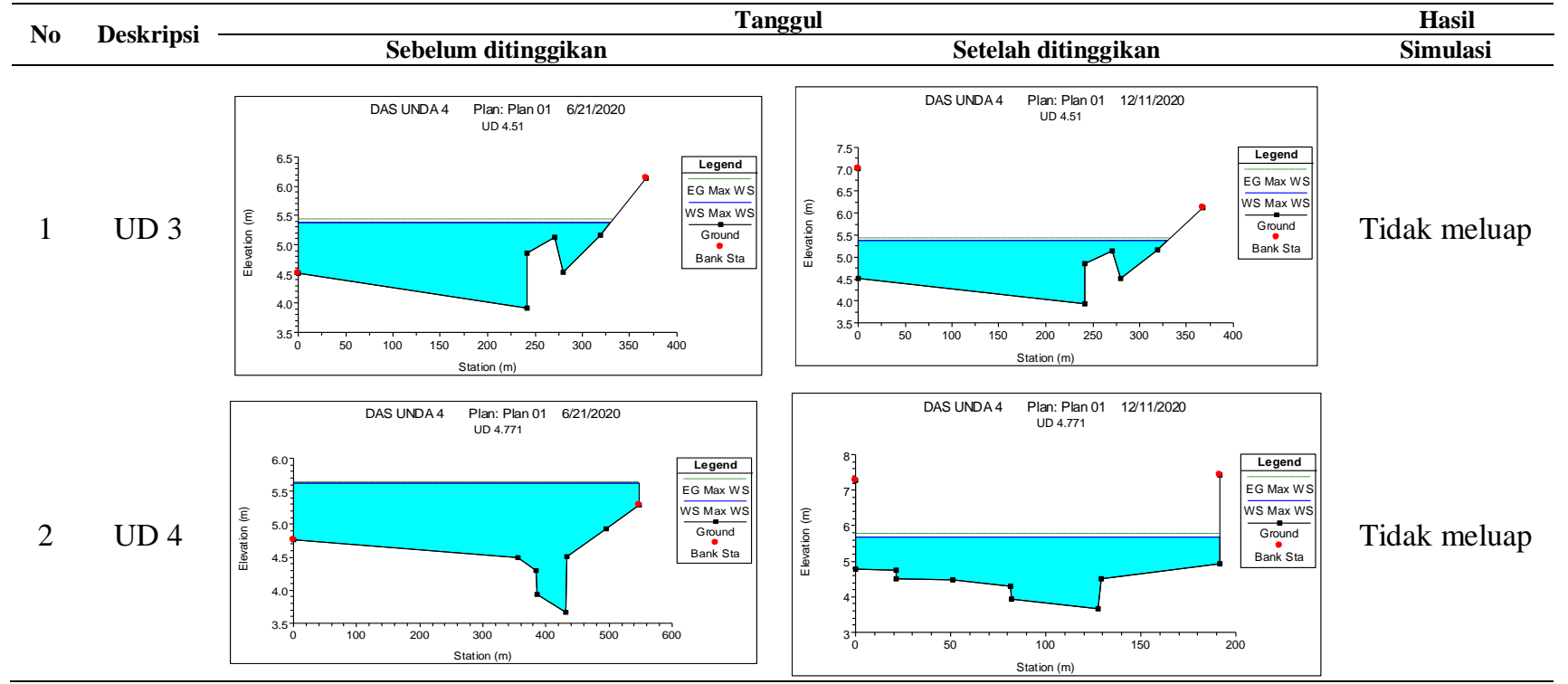




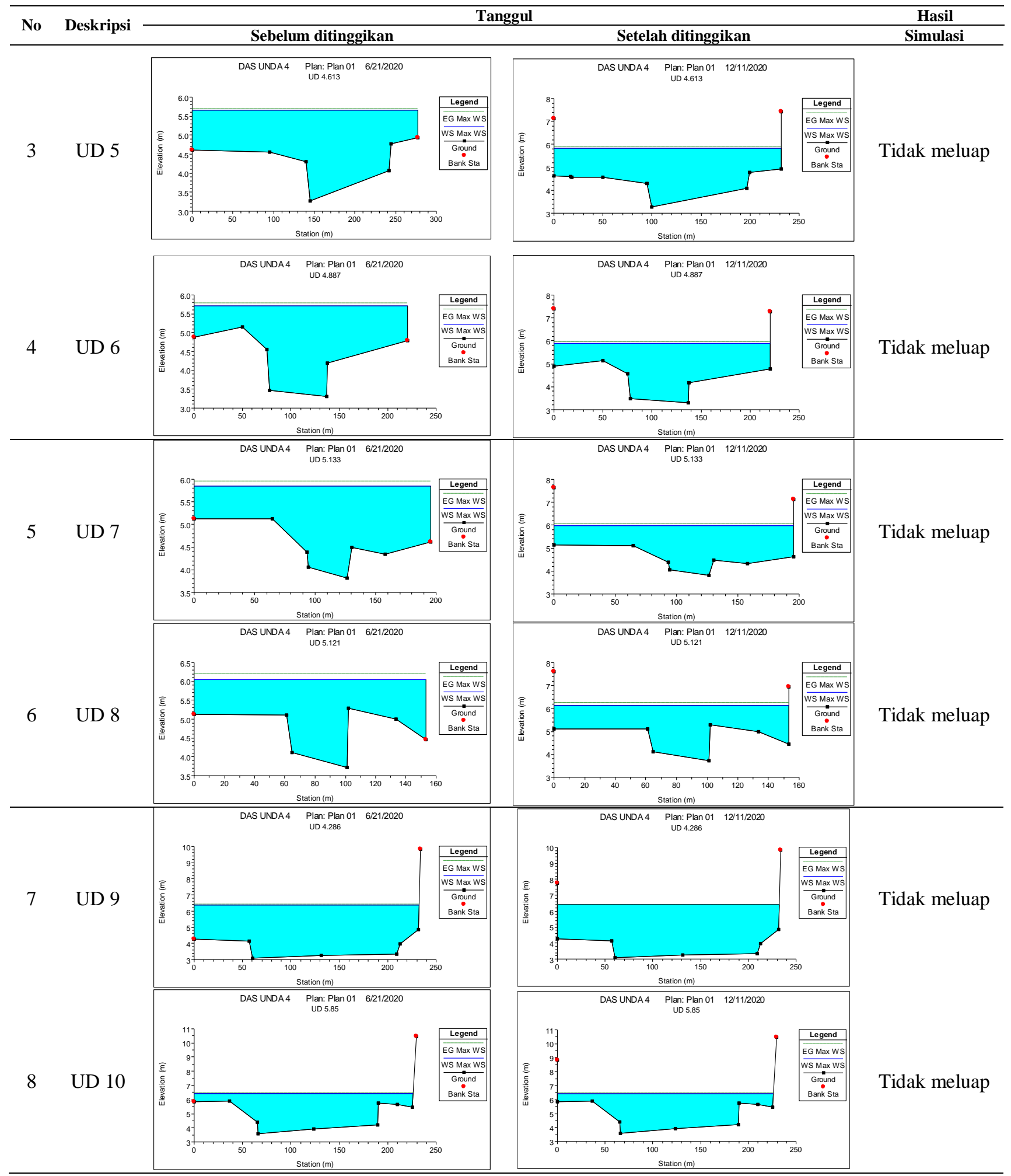




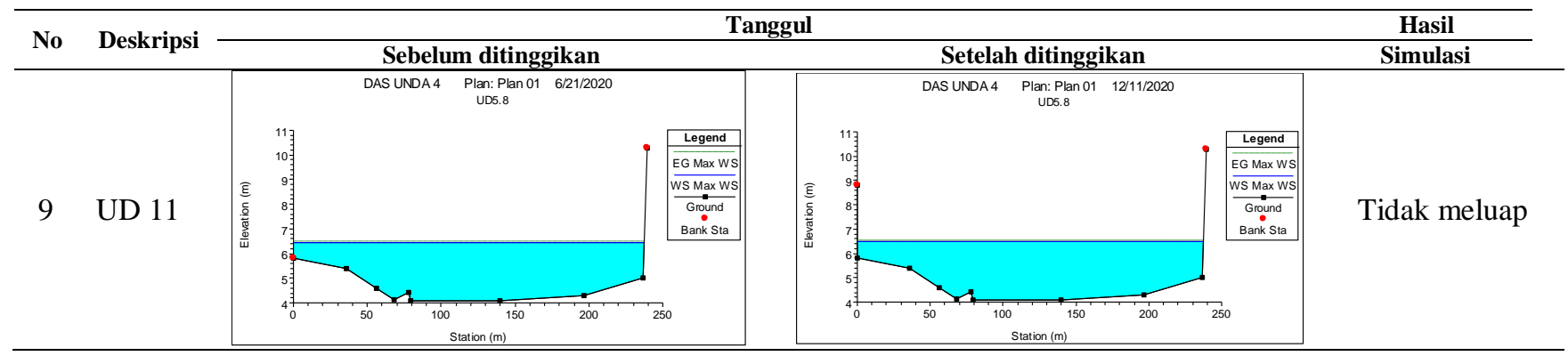

Berdasarkan Tabel 4.2 diatas kondisi panampang alami setelah direncanakan peninggian tanggul setinggi 2,0 m sampai dengan 2,5 m sesuai dengan muka air banjir dengan software HEC-RAS dinyatakan penampang alami tidak meluap lagi.

\section{5 .KESIMPULAN}

Debit banjir kala ulang 50 tahun dengan pemodelan HEC-HMS di Sungai Unda mencapai $350.3 \mathrm{~m}^{3} / \mathrm{dt}$. Pada penampang di hilir Sungai Unda beberapa mengalami luapan seperti pada penampang UD 3 dan UD 11 (setelah jembatan By Pass Ida Bagus Mantra) sepanjang 1052,34 m ke arah hilir sungai. Hasil running awal berdasarkan debit banjir kala ulang 50 tahun sebesar 350,3 m3/detik menyebabkan luapan air pada penampang alami di hilir sungai yaitu antara UD 3 sampai dengan UD 11 setinggi 1,5 m sampai dengan 3,0 m sepanjang 1052,34 $\mathrm{m}$ ke arah hilir. Posisi ini berada di hilir jembatan By Pass Ida Bagus Mantra. Running HEC-RAS dilanjutkan dengan merencanakan tinggi tanggul antara 2,0 m sampai dengan 2,5 m pada posisi UD 3 sampai dengan UD 11. Hasil running menyatakan sudah tidak terjadi luapan pada desain tanggul antara 2,0 m sampai dengan 2,5 meter.

\section{DAFTAR PUSTAKA}

Affandy, N.A., Anwar, N. 2011. Pemodelan Hujan-Debit Menggunakan Model HEC-HMS Di Das Sampean Baru. Seminar Nasional Penanganan Kegagalan Pembangunan Dan Pemeliharaan Infrastruktur, (5): 51-60.

Fadlillah, M.F., Hadiani, R., Solichin, S. 2018. Analisis Kekeringan Hidrologi Berdasarkan Metode Normalized Difference Vegetation Index (Ndvi) Di Daerah Aliran Sungai Alang Kabupaten Wonogiri. Jurnal Riset Rekayasa Sipil, 2(1): 34.

Kawet, L., Halim, F. 2013. Studi Perbandingan Hidrograf Satuan Sintetik Pada Daerah Aliran Sungai Ranoyapo. Sipil Statik, 1(4): 259-269.

Lashari, Kusumawardani, R., Prakasa, F. 2017. Analisa Distribusi Curah Hujan Di Area Merapi Menggunakan Metode Aritmatika Dan Poligon. Jurnal Teknik Sipil Dan Perencanaan, 19(1): 39-46.

Marthina, S., Rapar, E., Mananoma, T., Wuisan, E.M., Binilang, A. 2014. Analisis Debit Banjir Sungai Tondano Menggunakan Metode HSS Gama I Dan HSS Limantara. Sipil Statik, 2(1): 13-21.

Sarminingsih, A. 2018. Pemilihan Metode Analisis Debit Banjir Rancangan Embung Coyo Kabupaten Grobogan. Jurnal Presipitasi : Media Komunikasi Dan Pengembangan Teknik Lingkungan, 15(1): 53.

Suprayogi, R.M.S. 2012. Kajian Hujan-Aliran Menggunakan Model Hec-Hms Di Sub Daerah Aliran Sungai Wuryantoro Wonogiri, Jawa Tengah. 2: 150-157.

Tikno, S., Hariyanto, T., Anwar, N., Karsidi, A., Aldrian, E. 2016. Aplikasi Metode Curve Number Untuk Mempresentasikan Hubungan Curah Hujan Dan Aliran Permukaan Di Das Ciliwung Hulu - Jawa Barat. Jurnal Teknologi Lingkungan, 13(1): 25.

Triatmodjo, B. 2008. Hidrologi Terapan. Maret 2008. Yogyakarta: Beta Offset Yogyakarta.

Wigati, R., Soedarsono, S. 2016. Normalisasi Sungai Ciliwung Menggunakan Program HEC-RAS 4.1 (Studi Kasus Cililitan - Bidara Cina). JURNAL FONDASI, . 